\title{
HOW COMMUNITY ATTITUDES CAN STRENGTHEN ARGUMENTS FOR CHANGING THE LEGAL STATUS OF ANIMALS
}

\author{
GEETA SHYAM ${ }^{1}$ \\ ${ }^{1}$ Monash University, Faculty of Law, Wellington Road, Clayton VIC 3800, Australia. ORCID: 0000-0002- \\ 4797-9573, Email: geetashree.shyam@monash.edu
}

\begin{abstract}
The current legal categorisation of animals as property has its historical roots in Roman Law. The long history of this status prompts one to wonder whether it reflects modern community attitudes. It is, however, difficult to answer this question, as there is a dearth of empirical data on attitudes towards the legal status of animals. In light of the widely-accepted relationship between law and community attitudes, particularly in democratic societies, this paper highlights the need for empirical examinations of social attitudes towards the legal status of animals. It is suggested that such empirical exercises can help scholars and lawmakers more accurately understand whether a change in the legal status of some or all animals is politically achievable. Empirical studies of community attitudes can also provide direction to scholars, who theorise legal frameworks to define the legal status of animals, and animal advocacy groups, which seek to educate the community about the legal status of animals.

KEYWORDS: legal status of animals, animals as property, animal personhood, animal rights
\end{abstract}

Historian Yuval Noah Harari (2011) points out that what distinguishes Homo sapiens from other species of animals is our ability to co-operate with a large number of individuals. Homo sapiens have the unique ability to form large groups and to create social order amongst millions of people. This ability, which Harari explains emerged 
as part of the Cognitive Revolution, is enabled through the creation of fiction or what Harari describes as imagined realities. Nations, corporations and laws, for example, do not exist in real; they are imagined entities or systems developed to enable a large number of humans to cooperate. To change how society is organised, or how power is distributed, a large enough number of people ought to be convinced about new fiction.

Herein lies the challenge surrounding the legal status of animals. The role of legal fiction is all too familiar for animal lawyers. Indeed, fiction is often brought up in debates and litigation about the legal status of animals. A legal person, it is frequently argued, does not necessarily connote a human being. It is a construct of the law that can be, and already has been, extended to include non-human entities, such as corporations, rivers and idols. The task of "animal rights" advocates, therefore, is to convince legal or political institutions that this fictional concept of personhood should be expanded to include some or all animals. If successful in doing so, the legal fiction regulating human-animal relations would potentially carry significant implications for society.

This paper emphasises the need to understand community attitudes towards the legal status of animals better. It suggests that empirical examinations of social attitudes can provide valuable insight into the debate concerning the categorisation of animals as property. In particular, knowledge of community attitudes can provide a better sense of whether a change in the legal status of some or all animals would be politically achievable. It can also provide direction to scholars who theorise legal frameworks to define the legal status of animals. Such data can also guide the educational agenda of advocacy groups, as they can identify issues that are not salient or well understood in the community.

The paper first examines the legal status of animals as property, including the origins and implications of this status. It then provides an overview of various different theoretical frameworks for making animals subjects, rather than objects, of the law. It also notes the scepticism expressed by some scholars in respect of proposals to change the legal status of animals. It becomes evident at this point that the hypotheses made in relation to the feasibility of implementing any of those models are generally based on intuition rather than relevant empirical data. This paper then examines the relationship between law and society to explain the importance of gathering empirical data on attitudes towards the property status of animals. The next part observes that such empirical evidence is currently lacking; it then proceeds to highlight the findings and implications of an Australian study that reveals a lack of community awareness about the legal status of animals and indicates that attitudes towards the legal status of animals are variegated. Finally, this paper concludes by providing direction for future research in this space.

To clarify, it is not the intention of this paper to suggest that the legal status of animals should be determined by community attitudes alone. It is appreciated that such an exercise can be misguided, as community attitudes may not always be aligned with moral principles. Further, human behaviour may not always accord with prevailing social values (Gibson 1985). Even though certain values may be highly regarded in society, economic or habitual factors may compel humans to act contrary to those values. 
Additionally, empirical data may not always provide an accurate account of community attitudes. For example, often, respondents do not have an opinion about questions they are asked in a survey, especially where they relate to complex issues (Burstein 2006). In such cases, reliance on empirical data alone can be imprudent. The aim of this paper, therefore, is merely to highlight the value of measuring and understanding community attitudes in informing the debate about the legal status of animals and in determining an appropriate legal status for some or all animals.

\section{THE LEGAL STATUS OF ANIMALS}

Most animals in western countries are classified as things or property. Property rights in respect of wild animals are generally more restricted in comparison to domestic animals, but they lack personhood, nevertheless. The legal categorisation of animals as property can be traced at least as far back as Roman Laws. Under Roman Law, everything was divided into three legal categories: personae (persons), res (things) and actiones (actions) (Naffine 2009; Thomas 1976). Persons were entities capable of being affected by the law, while things were rights and duties that persons could have. Thus, persons were the subjects of the law, while things were objects of the law. Within this tripartite system, animals were classed as things (Pottage 2004). Roman Law ultimately inspired civil and common law systems throughout the world, including the British Common Law system that went on to be adopted in many other British colonies (Cao 2015; Domingo 2011). The categories of persons and things and the legal objectification of animals were carried forward and kept alive in the process. The treatment of animals as the property was justified in later centuries by Christian beliefs. For example, eighteenth-century philosopher, William Blackstone (1794), explained that animals were the property of humans because God gave humans dominion over everything that lived on Earth. Secular beliefs too glorified the status of humans in light of humans' advanced cognitive abilities and, on that basis, provided further justification for the property categorisation of animals (Naffine 2012).

The categories of persons and things were never defined or clearly differentiated by Gaius and Justinian, the jurists who originally conceptualised and adopted these terms (Trahan 2008; Kurki 2017a). There is some indication that the categories were not intended to be exclusive. Salves, for instance, were categorised as both persons and things (Kurki 2017b). However, the meanings attached to the terms "person" and "thing" have remained elusive and contested. Indeed, there are debates today about the meaning and requirements of personhood.

While the legal divide between persons and things continues to be evident in common law and civil law systems, the categories have evolved over time to suit changing needs and times. Scientific, technological and social developments have blurred the lines between the two categories, giving rise to debates about the legal status of the unborn, the dead, non-biological machines and nature (Pottage 2004). In light of growing environmental consciousness, for example, a few rivers, forests and mountains around the world have been declared to be legal persons (Maloney 2018).

Similarly, scientific developments and changing relationships between humans and 
animals have called into question the appropriateness of the property status of animals. Towards the end of the $20^{\text {th }}$ century, philosophical and legal minds started to question whether animals should be persons rather than property. Francione (1995) was one of the first to argue that sentient animals should be persons rather than property and that all forms of animal use should be abolished as a result. Since then, a variety of arguments for and against animal personhood have been put forward in a passionate and growing debate.

Animals are different from other types of property. Unlike chairs and cars, animals are sentient, living beings. As objects of the law, they are theoretically at the mercy of persons who are subjects of the law. While there are undoubtedly animal welfare laws that recognise the sentience of animals and seek to curtail the property rights of humans with respect to animals, animals are unable to enforce the protections granted to them under those laws. That is because legal standing is required to enforce those protections, and legal personhood is generally a requirement for legal standing (Tudor 2010; Stein 1979; Bagaric and Akers 2012). A more serious implication of the property status of animals, some argue, is that animals are disqualified from bearing rights (Korsgaard 2013; Wise 2000). Not everyone agrees with this position, as some argue that animals as property can and do have rights, albeit in a weak form (Sunstein 2003; Favre 2010).

The property status of animals has a number of other implications. As personal property, which can be subject to ownership, sale, purchase, gifts and theft, animals are commodified. The commodification of animals is most apparent in animal farming and in the breeding, selling and relinquishing of companion animals (White 2016). The treatment of animals as commodities is problematic because it "enables the instrumental treatment [of animals] by others subject only to a de minimis standard of regulation" (Deckha 2015:64). At a symbolic level, too, the property status of animals promotes the objectification and instrumental treatment of animals. The semantics imply that animals are a means to an end, rather than ends in themselves. Such a perspective can overlook the inherent interests or intrinsic value of animals (Bogdanoski 2013).

\section{MAKING ANIMALS SUBJECTS OF THE LAW}

In light of the sentience of animals, as well as the shortcomings associated with the property status of animals, a debate has emerged about whether the property status of animals should be abolished. Those who are opposed to the property status of animals often contend that animals should be regarded as legal persons. Francione and Wise take this position, although the scope and approach of their arguments differ.

Francione $(1995 ; 1996 ; 2000 ; 2008 ; 2010)$ strongly opposes all forms of animal use, particularly the use of sentient animals. His position is premised on the belief that sentient animals, which possess some level of self-awareness, have an interest in living and not suffering. These interests, he argues, are incompatible with their characterisation as property. He points out that animals share an interest in not suffering from humans. Applying the principle of equal consideration, which requires likes to 
be treated alike, Francione argues that like humans, animals too should not be treated as property. Francione thus demands the abolition of the property status of sentient animals, and advocates for the recognition of their right not to be treated as property. Because he believes that personhood is a perquisite for legal rights, he calls for animals to be granted legal personhood.

The consequences of Francione's vision would be significant if materialised. He acknowledges that the implications of the abolitionist view are radical. It would mean that the institutionalised exploitation of animals for food, biomedical research, clothing and entertainment would have to end. Given the prevalence of animal-use practices today, it does seem unlikely that the community is likely to support an end to all forms of animal use. However, whether there is sufficient community support for the abolition of animal-use and whether there is sufficient community support for animal personhood or an alternative legal status for animals, are different questions. While the previous question is likely to be answered in the negative, there is a lack of empirical data from which the answer to the latter question can be extrapolated. Even if it appears that legal personhood for all sentient animals is too ambitious, it is worth questioning whether there might be adequate community support for changing the legal status of at least some animals.

Wise $(2000 ; 2002 ; 2004)$ pursues this question. While Francione's arguments are founded on purely moral considerations, Wise accepts that "progress is impeded by physical, economic, political, religious, historical, legal and psychological obstacles” (2002:9). Wise, therefore, advocates for the personhood of only a small class of animals, for the purposes of a limited set of rights. In particular, he argues that animals that possess practical autonomy should be recognised as legal persons who are entitled to the rights to liberty and equality. A being has practical autonomy if they can desire, intentionally try to fulfil their desire, and possess some level of self-awareness. Wise suggests that the more the behaviour of an animal resembles human behaviour, and the taxonomically closer the animal is to humans, the more likely the animal is to possess practical autonomy. At the very least, based on current scientific literature, Wise identifies great apes, Atlantic bottle-nosed dolphins, African elephants, and African grey parrots as animals that meet the requirements of personhood.

The peril of Wise's approach is that it could re-draw the lines of the existing hierarchy that places the human species over all other species. It would deny personhood to animals that lack practical autonomy, or animals that have not scientifically been proven to possess the required cognitive abilities. It should be remembered, however, that it is not Wise's intention to deny personhood to animals that lack practical autonomy. He makes it transparent that "[i]]f I was Chief Justice of the Universe, I might make the simpler capacity to suffer, rather than practical autonomy, sufficient for personhood and dignity rights" (2002:32). Wise employs a narrow-focused approach because he is conscious of the significant resistance to the idea of making all sentient animals legal persons, especially in light of the wide-ranging implications of a sentience-based strategy.

Not everyone who disagrees with the current legal status of animals pushes for 
animal personhood. Favre $(2000 ; 2004 ; 2004)$, for example, proposes a guardianship model. Animals would remain property under this model, but instead of having owners, they would have guardians who are required to act in the best interests of the animals. Favre is mindful that the legal status of animals depends in large part on what society thinks. On this basis, he stresses "it is important to distinguish first steps of change within the legal system, where maximum consensus ought to exist, versus the ultimate destination of legal change” (2004:236). Recognising political and social realities, Favre suggests an incremental approach ought to be taken where the property status of animals is modified rather than abolished.

Under this modified approach, title to an animal would be divided into legal and equitable elements. Humans would retain legal title to the animal, while animals would have equitable self-ownership. The legal title owner would owe duties directly to the self-owned animal and would be required to make decisions that are in the best interests of the self-owned animal. Self-owned animals would also have the ability, through court-appointed guardians or private parties, to enforce their legally recognised interests. Ultimately, Favre seeks to develop a model for animals that provides "an intermediate ground between being only property and being freed of property status, where the interests of animals are recognised by the legal system, but the framework of property law is still used for limited purposes" (2000:476). However, he acknowledges that this model too can only be implemented if it finds social acceptance.

More recently, recognising the social approval needed to make drastic changes to the legal status of animals, Favre (2010) proposed a more conservative model where sentient animals would be placed in a new subcategory of the property called "living property”. It is important to recognise that, unlike Francione and Wise, Favre contends that animals as property can and do have legal rights. Thus, he considers it ethically acceptable, at least in present times and subject to some modifications, to retain the property status of animals.

According to Favre, animals with DNA have inherent interests and moral value. Thus, the law ought to protect the interests of animals. Despite the broad implications of his position on the moral status of all, rather than just sentient animals, he proposes two qualifications for eligibility into the category of living property. First, the animals have to be knowingly possessed by humans. This would exclude most wild animals. Second, the category would be restricted to vertebrate animals to "keep the discussion focused on those who have the most complex needs and for whom we can do the most" (2010:1045-6); Favre does suggest, however, that this line could be redrawn in the future as more scientific information on the interests of non-vertebrate animals becomes available. Because legal personality is a prerequisite for legal standing, the existing property would be granted limited personality. This would enable living property to enforce their interests. As to which interests the law would protect, Favre believes it is a "social and, therefore, political judgement" (2010:1053). Hence, the law would protect those interests that can garner sufficient political support.

Pietrzykowski $(2017 ; 2018)$ also offers an innovative approach for the legal treatment of animals. Rather than advocate for animal personhood, he believes that a new legal category ought to be established for sentient animals. The new legal category, 
called non-personal subjects of law, would make sentient animals subjects of the law without granting them legal personhood. Pietrzykowski's approach is constructed on the belief that sentient animals do not belong in either of the categories of persons or things. He is of the opinion that the sentience of animals makes their treatment as things inappropriate, but they also lack capacities that are generally associated with personhood. Pietrzykowski further suggests that personhood is not necessary for animals to become subjects of law because, contrary to popular belief, the categories of persons and things are not exhaustive. He contends that the establishment of a new legal category would recognise the similarities between humans and animals without ignoring the differences between humans and other animal species.

As non-personal subjects of law, animals would be capable of bearing rights. In particular, animals would have a single right to have their interests considered in all decisions affecting the realisation of those interests, including decisions made by lawmakers and individuals. This right would ensure that the interests of animals cannot be ignored. Pietrzykowski accepts that merely mandating the consideration of animals' interests may not produce significantly different outcomes from the present framework where animals are property. He explains, however, that his goal is not to provide for the immediate eradication of all animal suffering but to design a system for facilitating gradual attitudinal shifts and improvements to the conditions of animals. Accordingly, the legal protections provided to animals must not go beyond predominant social expectations; rather, they should be reconcilable with existing practices. It follows for Pietrzykowski that the extent to which this model will be able to protect the interests of animals better will depend on the evolution of social attitudes.

With several different models proposed for defining the legal status of animals, it is natural to wonder which of these models could successfully be implemented with the least amount of controversy or resistance. Currently, there is limited empirical data that sheds much light. Without empirical evidence, one can only speculate about whether any of those alternative legal statuses for some or all animals would find social acceptance. Indeed, arguments in favour of abolishing the property status of animals are often met with pessimism. These too appear to be based on intuition rather than empirical evidence.

Garner (2002; 2010a; 2010b; 2016), for example, does not necessarily disagree with the goal of abolishing the property status of animals. However, he contends that the ambition is unachievable in the current political climate. Distinguishing between what is ethical and what is politically achievable, Garner asserts that the property status of animals is "merely a reflection of wider societal attitudes" (2002:80). Garner's calculations may appear correct in light of existing animal-use practices. However, without empirical data, it is difficult to assess the extent to which Garner's predictions are correct. While his conclusions about social attitudes might indeed be accurate, it is also possible that attitudes towards the legal status of animals are more nuanced. It may be that there is sufficient community support for the abolition of the property status of at least some animals, such as the cognitively advanced animals or companion animals.

For Lovvorn (2006), arguing for the abolition of the property status of animals is an “intellectual indulgence” (p. 139). Relying on a number of American polls, he asserts 
that abolishing the property status of animals is politically unachievable. The data Lovvorn refers to does suggest a lack of support for bans on the use of animals in medical research, product testing, hunting and clothing. However, the data does not illuminate attitudes towards the legal categorisation of animals as property or alternative legal status. The statistical evidence that forms the basis of Lovvorn's sceptical position does not necessarily indicate community support for the current legal status of animals.

Similar predictions have been made more recently by Cupp (2007; 2016; 2018). Cupp agrees that human-animal relations in urbanised and industrialised societies commonly involve emotional, rather than purely economic, connections. He further accepts that public support for better animal protection laws is likely to continue to grow. He believes, however, that most people oppose the idea of legal personhood for animals. Again, there is a lack of empirical data to back this cynicism. The deductions made by Garner, Lovvorn and Cupp from current social practices may indeed be correct. However, without empirical evidence, they remain speculations that do not necessarily weigh any greater than the assumptions embedded in the works of those who propose an alternative legal status for animals.

A review of existing literature on the legal status of animals thus highlights the need to measure community attitudes towards the legal status of animals. Such empirical research is needed to test the hypothesis that abolition of the property status of animals is politically unachievable. It is also needed to ascertain whether the alternative legal statuses for animals proposed by proponents of change would enjoy community support. This data may ultimately add strength to arguments for abolishing the property status of some or all animals, particularly in light of the interconnectedness between law and social attitudes.

\section{THE RELATIONSHIP BETWEEN LAW AND SOCIETY}

To appreciate the importance of surveying community attitudes towards the legal status of animals, the relationship between law and society needs to be understood. It will perhaps seem obvious to most people that "[1]aw is a social phenomenon" (Anleu 2000:1). Notwithstanding this intuitive belief, law and society scholars have been studying the relationship between law and society for a long time. It is widely accepted within this scholarly field that law mirrors or reflects the values of the society in which it operates (Selznick 2006). Friedman (1996), for example, observes specifically in respect of western legal systems:

Legal systems do not float in some cultural void, free of space and time and social context; necessarily, they reflect what is happening in their own societies. In the long run, they assume the shape of those societies, like a glove that moulds [sic] itself to the shape of a person's hand (p. 72).

The extent to which law reflects community attitudes should not be overstated. As Tamanaha (2001) thoroughly explains, there are a number of reasons why the law often does not reflect the prevailing attitudes in society. The voluntary or involun- 
tary transplantation of laws is one such cause, resulting in an alien society having a greater influence over the laws of a particular state. An excellent example of this is the adoption of colonial laws in countries such as Australia, a process through which the property status of animals was inherited.

Further, Tamanaha points out that complex societies have warranted sophisticated commercial and administrative laws that are inspired to a greater extent by economic considerations than social values. Corporations, securities and other complex commercial legislation provide good examples. Globalisation too has diluted the extent to which laws mirror a local society, as often laws are introduced by a state to remain part of international institutions or agreements, such as the European Union or the General Agreement on Tariffs and Trade.

However, despite presenting a detailed critique of the mirror thesis, even Tamanaha does not deny the relationship between law and society. To say that a range of factors can influence the content of law does not entirely negate the relationship between law and society. Arguably, even complex commercial and administrative legislation are founded on social values of justice and fairness. It is true, as Tamanaha suggests that societies now have less influence over laws in comparison to traditional and less complex societies. Nonetheless, an essential connection between law and society remains.

The connection between law and society is especially expected in democratic societies. A democratic society requires that "decisions implemented on its behalf reflect the preferences of its members" (Przeworski 2010). It is premised on the principle of self-governance or "rule by the people" (Tideman 1994). The rationale behind democracy is that citizens are not coerced into complying with the legal order. Instead, they freely provide consent to be bound by that legal order (Komberg and Clarke 1992). Society's influence over law may not be obvious or direct in a representative democracy, where representatives are chosen by society to govern the country (Schumpeter 2013). Nevertheless, the idea behind a representative democracy is still to enforce the will of the people - or at least a majority of the people - through the election process and representative governments (Plotke 1997).

It would be naïve to suggest that society is homogenous. While "[r]epresentative government was born under an ideology that postulated a basic harmony of interests in society" (Przeworski 2010: 20), it is certainly not the case today. Societies today are more likely to be pluralistic in nature, where there are competing values and attitudes (Jacobs 2014). Consequently, self-governance in such societies is better described as a system where "the reins of government should be handed to those who command more support than do any of the competing individuals or teams" (Schumpeter 2013:272). In representative democracies, therefore, elected governments and legislatures seek to balance and juggle conflicting public views.

A benefit of aligning the law with society's expectations is that people are more likely to comply with laws that conform to community attitudes (Tyler 1990). Such conformity provides substantive legitimacy. It is achieved where the law is perceived by the community to be consistent with community attitudes (Wintgens 2007). In other words, legitimacy is derived from the rational justifications for the law. It is in light of the tendency of people to comply with substantively legitimate laws that Tyler and 
Darley (2000) suggest that "focusing upon the social values held by the public is one key component of an effort to create and sustain a legal order, the effectiveness of which is linked to the consent and cooperation of citizens" (p. 708).

The connection between law and society implies that legal change and social change are also related. That legal change follows social change is not controversial. This is demonstrated by the development and strengthening of animal welfare laws throughout the world (Herzog, Rowan and Kossow 2001). What is contentious is the idea that legal change can lead to social change. Many accept that legal change can engineer social change (Friedman 1973; Castro 2012). The regulation of smoking and the supply of tobacco products, for example, have been found to have changed smoking habits in different societies (Cummings 2002; Orbell 2009; Lidón-Moyano 2017) However, it is unlikely that legal change can affect radical social change. Law is unlikely to inspire social change if it conflicts too much with prevailing values and moral ideals, or if the law is not supported by powerful and elite members of society (Vago and Barkan 2017). Nevertheless, while the extent to which social change and legal change can lead each other may not be equal, there is a growing recognition that law and society have a circular, reciprocal relationship. Both occur in tandem and influence each other (Sifris 2010).

\section{WHAT DOES SOCIETY THINK ABOUT THE LEGAL STATUS OF ANIMALS?}

Once the relationship between law and society is comprehended, and the history of the property characterisation of animals appreciated, the value of examining social attitudes towards the legal status of animals becomes apparent. Currently, it is difficult to describe community attitudes in this context accurately. Data about attitudes towards the legal status of animals is scarce. Therefore, it is difficult to ascertain the extent to which different societies agree or disagree with the legal classification of animals as property. As a result, it is difficult to draw conclusions about whether the law is consistent with modern attitudes. Further, as highlighted earlier, in the absence of such knowledge, one can only speculate about whether legal subjecthood for animals, in any form, would enjoy communal acceptance.

One small-scale exploratory study undertaken in the Australian state of Victoria (Shyam 2018) attempted to explore such attitudes and address these questions. A survey of 287 Victorians aged over 18 was undertaken in Melbourne city and two rural regions of Victoria (Ballarat and Gippsland) between December 2013 and July 2014. A short questionnaire consisting of eleven questions was designed to ascertain the extent of the respondents' knowledge of the property status of animals, as well as the extent to which they agreed or disagreed with that status. The self-administered survey was conducted at train stations, tram stops and bus stations, employing convenience (non-probability) sampling.

A key finding of this research was that knowledge of the property status of animals is lacking in society. The study found that over half of the respondents to the survey did not know that animals are legally classified as property. Additionally, a third of the respondents to the study did not know the implications of legally categorising 
animals as property. Many of the respondents thought that the property status of animals entitles animals to legal protections for their welfare. This lack of knowledge and understanding is problematic because if members of a society are unaware of the property status of animals and the implications of such classification, they are unlikely to challenge, or think critically about, that legal status. Moreover, without such awareness, society is unlikely to evaluate their preference for alternative legal statuses for animals, such as those described above.

Noting the lack of awareness about the legal status of animals, this study reported common disagreement with the property categorisation of animals. Most respondents to the study disagreed with the property status of at least some animals, although the study did not ask respondents to identify animals whose property status they did not approve of. Before asking respondents whether they agreed with the legal classification of animals as property, the survey also asked respondents how they perceived their pets (if applicable), farm animals and wild animals. The results indicated that the majority of respondents did not perceive any of those categories of animals as property, although farm animals were more likely to be perceived as property in comparison to pets and wild animals. The results of this study cannot be generalised due to the small sample size and the use of non-probability sampling. However, to the extent that the results provide a snapshot of modern attitudes towards animals in Victoria, these results do lend support to the argument that the property status of animals fails to reflect community attitudes.

This study also highlighted that community attitudes towards animals are variegated. While pets were largely perceived as "members of the family" or "friends", farm animals were more likely to be seen as "living beings different to humans". Wild animals were the least likely to be seen as property, and were mostly perceived to be "important national treasures". These findings confirmed that different sentiments are attached to different kinds of animals. Thus, the study also adds weight to the proposition that different kinds of animals ought to be assigned a different legal status. Legal systems such as the one in Australia already provide different levels of protection for different kinds of animals. For example, in all Australian states and territories, the welfare of companion animals is protected to a greater extent than farm animals, and native animals receive greater protection than introduced species of animals (White 2013). Such legal systems are therefore already capable of distinguishing between different kinds of animals. As such, it is not difficult to conceive of a legal framework that assigns different legal statuses for different kinds of animals.

\section{THE PATH TOWARDS A NEW LEGAL FICTION}

In light of the intricate relationship between law and society, it is worthwhile examining whether centuries-old laws continue to reflect contemporary attitudes. This is especially useful where an aspect of the law starts to feel counter-intuitive, such as with respect to the legal categorisation of animals as property. In this context, empirical studies can help shed light on whether the categorisation of animals as property is consistent with community attitudes. 
This paper has highlighted that a lot of intellectual effort is being expanded on formulating models for defining the legal status of animals and hypothesising about which of these models will work. There is also much deliberation about whether any change in the legal status of animals would be socially acceptable. It is suggested that empirical inquiry of community attitudes towards the legal status of animals can inform this debate and guide the development of legal models that can successfully be implemented.

Accordingly, it is suggested that attitudes towards animals, especially their legal status, should continue to be surveyed. For a truthful understanding of these attitudes, such surveys should ascertain respondents' awareness and understanding of the property status of animals. The surveys should also account for variegated attitudes towards the legal status of animals, and therefore ask respondents whether they agree with the property status of specific types of animals.

If empirical studies continue to support the proposition that some or all animals are not perceived as property in contemporary societies, arguments for abolishing the property status of those animals will be strengthened. Such data can then be used to persuade and even pressure lawmakers to change the legal status of the relevant kinds of animals. Even where different sentiments are attached to different kinds of animals, the data may help identify animals whose legal status may be easier to change than others.

Given that there appears to be a lack of understanding in the community about the legal status of animals, education will have an important role to play in efforts to change the legal status of animals. The public needs to be educated about the legal status of animals as property, as well as about the implications of giving animals that legal status. This education may emanate from advocacy groups in the form of awareness campaigns. Incorporation of this subject into school curriculums could also ensure a demographically wider understanding of the legal status of animals. This knowledge will empower the community to develop informed opinions, and in the longer term, prompt lawmakers to review and reassess the legal status of animals.

Education, whether delivered by educational institutions or advocacy groups, can be informed by empirical data as well as animal law scholarship. Empirical data will highlight knowledge gaps in the community, while animal law scholarship will help determine and deliver the educational content. For this reason, it is vital that scholars continue to research and deliberate on the implications of legally classifying animals as property, and to debate about how animals should be categorised by the law. Such academic pursuits should use existing and new empirical data as a reference to innovate or develop alternative legal models for defining the legal status of animals. Thus, if attitudes towards animals are variegated, scholars should strive to understand and reflect the attitudinal nuances in alternative models. Aside from feeding into educational initiatives, such scholarship can also assist lawmakers in their reform agendas.

There is no doubt that animal welfare laws are a useful way of eliminating or minimising the suffering of animals. Efforts to improve animal welfare laws should, therefore not be reduced. It is important to realise that animal welfare laws do not stand in opposition to arguments for abolishing the property status of animals. The need for 
such laws will continue to exist even if animals become subjects of the law through personhood or some other legal categorisation. Just as specific laws exist for the protection of workers, who are legal persons, it will be necessary to have laws for the protection of animal subjects. Animal welfare laws may need to be modified to reflect the new legal status of animals, but their use will not become redundant.

Notwithstanding the necessity of animal welfare laws, opportunities to improve the legal status of animals must be seized. Failure to do so may keep a fiction alive that makes it easier to facilitate the subjection of animals to pain and suffering. Capitalising on modern community perceptions of animals may add weight to arguments for changing the legal status of animals, thereby making it easier to shatter the fabricated conception of animals as property. As Harari cautions, imagined reality has become more powerful over time, to the point that the survival of objective realities, such as rivers, trees and animals, now depends on the grace of imagined entities.

FUNDING: This research received no external funding.

CONFLICT OF INTEREST: The author declares no conflict of interest.

ACKNOWLEDGEMENTS: I would like to thank the anonymous peer reviewers for their valuable feedback on this paper.

\section{REFERENCES}

Anleu, Sharyn L R. 2000. Law and Social Change. London, UK: Sage Publications.

Bagaric, Mirko and Keith Akers. 2012. Humanising Animals: Civilising People. Sydney, Australia: $\mathrm{CCH}$.

Bogdanoski, Tony. 2013. “A Companion Animal's Worth: The Only 'Family Member' Still Regarded as Legal Property.” Pp. 84-103 in Animal Law in Australasia: Continuing the Dialogue. $2^{\text {nd }}$ ed. Annandale, NSW: The Federation Press.

Blackstone, William. 1794. Commentaries on the Laws of England. $12^{\text {th }}$ ed. London, UK: A Strahan and W. Woodfall.

Burstein, Paul. 2006. "Why Estimates of the Impact of Public Opinion on Public Policy are Too High: Empirical and Theoretical Implications.” Social Forces 84(4):2273.

Cao, Deborah. 2015. Animal Law in Australia. Pyrmont, Australia: Law Book Co of Australia.

Castro, Paula. 2012. "Legal Innovation for Social Change: Exploring Change and Resistance to Different Types of Sustainability Laws.” Political Psychology 33(1):105.

Cummings, Michael K. 2002. "Programs and Policies to Discourage the use of Tobacco Products.” Oncogene 21:7349.

Cupp, Richard Jr. 2007. "A Dubious Grail: Seeking Tort Law Expansion and Limited Personhood as Stepping Stones towards Abolishing Animals’ Property Status.” SMU Law Review 60(1): 3.

Cupp, Richard Jr. 2016. "Focusing on Human Responsibility Rather than Legal Personhood for Nonhuman Animals.” Pace Environmental Law Review 33:517.

Cupp, Richard Jr. 2018. “Litigating Nonhuman Animal Legal Personhood.” Texas Tech 
Law Review 50:25.

Deckha, Maneesha. 2015. "Vulnerability, Equality, and Animals." Canadian Journal of Women and the Law 27(1):47.

Domingo, Rafael. 2011. “Gaius, Vattel and the New Global Law Paradigm.” The European Journal of International Law 22(3):627.

Favre, David. 2000. “Equitable Self-ownership for Animals.” Duke Law Journal 50:473. Favre, David. 2004. "A New Property Status for Animals: Equitable Self-ownership." Pp. 234-50 in Animal Rights: Current Debates and New Directions. New York: Oxford University Press.

Favre, David. 2010. "Living Property: A New Status for Animals within the Legal System.” Marquette Law Review 93:1021.

Francione, Gary L. 1995. Animals, Property and the Law. Philadelphia PA: Temple University Press.

Francione, Gary L. 1996. Rain without Thunder: The Ideology of the Animal Rights Movement. Philadelphia PA: Temple University Press.

Francione, Gary L. 2000. Introduction to Animal Rights: Your Child or the Dog? Philadelphia PA: Temple University Press.

Francione, Gary. 2007. "Reflections on Animals, Property and the Law and Rain Without Thunder." Law and Contemporary Problems 70:9.

Francione, Gary L. 2008. Animals as Persons: Essays on the Abolition of Animal Exploitation. New York: Columbia University Press.

Francione, Gary L. and Robert Garner. 2010. The Animal Rights Debate: Abolition or Regulation? New York: Columbia University Press.

Friedman, Lawrence M. 1973. “General Theory of Law and Social Change.” Pp. 17- in Law and Social Change. Toronto, Canada: Osgoode Hall Law School.

Friedman, Lawrence. 1996. "Borders: On the Emerging Sociology of Transnational Law." Stanford Journal of International Law 32:65.

Garner, Robert. 2002. "Political Ideology and the Legal Status of Animals.” Animal Law 8:77.

Garner, Robert. 2010a. "A Defence of a Broad Animal Protectionism” Pp. 108-142 in The Animal Rights Debate: Abolition or Regulation? New York: Columbia University Press.

Garner, Robert. 2010b. “Animals, Ethics and Public Policy.” The Political Quarterly 81(1): 123.

Garner, Rober. 2016. “Animals, Politics and Democracy.” Pp. 103-18 in The Political Turn in Animal Ethics. London, UK: Rowman \& Littlefield International.

Gibson, Dale. 1985. "Public Opinion and Law: Dicey to Today.” Pp. 1 in Law in a Cynical Society? Opinion and Law in the 1980's. Calgary, Canada: Carswell Legal Publications.

Harari, Yuval Noah. 2011. Sapiens: A Brief History of Humankind. London, UK: Vintage. Herzog, Harold, Andrew N Rowan and Daniel Kossow. 2001. "Social Attitudes and Animals.” Pp 55-69 in The State of the Animals. Washington DC: Humane Society Press.

Jacobs, Lawrence R. 2014. “The Contested Politics of Public Value.” Public Administra- 
tion Review 74(4):480.

Komberg, Allan and Harold D Clarke. 1992. Citizens and Community: Political Support in a Representative Democracy. New York: Cambridge University Press.

Korsgaard, Christine M. 2013. "Personhood, Animals, and the Law.” Think 12(34):25.

Kurki, Visa A. J. 2017a. "Why Things Can Hold Rights: Reconceptualising the Legal Person.” Pp. 69-90 in Legal Personhood: Animals, Artificial Intelligence and the Unborn. Cham, Switzerland: Springer.

Kurki, Visa. 2017b. “Animals, Slaves, and Corporations: Analysing Legal Thinghood.” German Law Journal 18(5):1069.

Lidón-Moyano, Cristina. 2017. "Impact of the Spanish Smoking Laws on Tobacco Consumption and Secondhand Smoke Exposure: A Longitudinal Population Study.” Addictive Behaviours 75:30.

Lovvorn, Jonathan R. 2006. "Animal Law in Action: The Law, Public Perception, and the Limits of Animal Rights Theory as a Basis for Legal Reform.” Animal Law 12:133.

Maloney, Michelle. 2018. "Environmental Law: Changing the Legal Status of Nature: Recent Developments and Future Possibilities." Law Society of NSW Law Journal 49:78.

Naffine, Ngaire. 2009. Law's Meaning of Life: Philosophy, Religion, Darwin and the Legal Person. Portland, OR: Hart Publishing.

Naffine, Ngaire. 2012. "Legal Personality and the Natural World: On the Persistence of the Human Measure of Value." Journal of Human Rights and the Environment 3:68.

Orbell, Sheina. 2009. "Social Cognitive Beliefs, Alcohol and Tobacco Use: A Prospective Community Study of Change Following a Ban on Smoking in Public Places.” Health Psychology 28(6):753.

Pietrzykowski, Tomasz. 2017. “The Idea of Non-personal Subjects of Law.” Pp. 49-68 Legal Personhood: Animals, Artificial Intelligence and the Unborn. Cham, Switzerland: Springer.

Pietrzykowski, Tomasz. 2018. Personhood Beyond Humanism: Animals, Chimeras, Autonomous Agents and the Law. Cham, Switzerland: Springer.

Plotke, David. 1997. "Representation is Democracy." Constellations 4(1):28.

Pottage, Alain. 2004. “Introduction: The Fabrication of Persons and Things.” Pp. 1-39 in Law, Anthropology and the Constitution of the Social: Making Persons and Things. Cambridge, UK: Cambridge University Press.

Przeworski, Adam. 2010. Democracy and the Limits of Self-Governance. New York, Cambridge University Press.

Schumpeter, Joseph A. 2013. Capitalism, Socialism and Democracy. Oxford, UK: Routledge.

Selznick, Philip. 2006. “The Jurisprudence of Communitarian Liberalism.” Pp 19-32 in Communitarianism in Law and Society. Lanham, MD: Rowman \& Littlefield Publishers Inc.

Shyam, Geeta. 2018. "Is the Classification of Animals as Property Consistent with Modern Community Attitudes?” The University of New South Wales Law Journal 41:1418-44.

Sifris, Adiva. 2010. "Lesbian Parenting in Australia: Demosprudence and Legal 
Change." Pp. 8-27 in Current Trends in the Regulation of Same-sex Relationships. NSW, Australia: Federation Press.

Stein, Leslie A. 1979. “The Theoretical Bases of Locus Standi” Pp. 3-23 in Locus Standi. Sydney, Australia: Law Book Co.

Sunstein, Cass R. 2003. “The Rights of Animals.” The University of Chicago Law Review 70(1):387.

Tamanaha, Brian Z. 2001. A General Jurisprudence of Law and Society. Oxford, UK: Oxford University Press.

Tideman, Nicolaus. 1994. "Capacities and Limits of Democracy.” AEA Papers and Proceedings 84(2):349.

Thomas, Joeseph A. C. 1976. Textbook of Roman Law. Amsterdam, Netherlands: North-Holland Publishing Company.

Trahan, J. R. 2008. "The Distinction between Persons \& Things: An Historical Perspective." Journal of Civil Law Studies 1:9.

Tudor, Steven. 2010. "Some Implications for Legal Personhood of Extending Legal Rights to Non-Human Animals.” Australian Journal of Legal Philosophy 35:134.

Tyler, Tom R. 1990. Why People Obey the Law. (New Haven, CT: Yale University Press). Tyler, Tom R. and John M Darley. 2000. "Building a Law-Abiding Society: Taking Public Views About Morality and the Legitimacy of Legal Authorities into Account When Formulating Substantive Law." Hofstra Law Review 28(3):707.

Vago, Steven and Steven E Barkan. 2017. Law and Society. $11^{\text {th }}$ ed. New York: Taylor Francis Group.

White, Steven. 2013. "British Colonialism, Australian Nationalism and the Law: Hierarchies of Wild Animal Protection.” Monash University Law Review 39(2):452.

White, Steven. 2016. "Standards and Standard-setting in Companion Animal Protection.” Sydney Law Review 38(4):463.

Wintgens, Luc J. 2007. "Legitimacy and Legitimation from the Legisprudential Perspective.” Pp. 3-42 in Legislation in Context: Essays in Legisprudence. New York: Ashgate.

Wise, Steven M. 2000 Rattling the Cage: Towards Legal Rights for Animals. New York: Perseus Publishing.

Wise, Steven, M. 2002. Drawing the Line: Science and the Case for Animal Rights. New York: Perseus Books.

Wise, Steven M. 2004. “Animal Rights, One Step at a Time.” Pp. 19-50 in Animal Rights: Current Debates and New Directions. New York: Oxford University Press.

\section{BIOGRAPHICAL NOTE}

Geeta Shyam is a Teaching Associate and Research Assistant at Monash University, Australia.

OPEN ACCESS: This article is distributed under the terms of the Creative Commons Attribution Non-commercial License (CC BY-NC 4.0) which permits any non-commercial use, and reproduction in any medium, provided the original author(s) and source are credited. 